\title{
MANFAAT ACCELEROMETER UNTUK PENGUKURAN AKTIVITAS FISIK
}

\author{
Angelica Anggunadi, Nora Sutarina \\ Program Studi Ilmu Kedokteran Olahraga FK UI, Jakarta \\ Email : dr_d0mb4@yahoo.com
}

\begin{abstract}
Various studies indicate that the occurrence of chronic diseases among senior people is strongly influenced by lifestyle with irregular physical activity or sedentary lifestyle undertaken when the individual were at young age. Furthermore, physical activities are known to be beneficial to support children and teenagers optimal growth. Sports and physical activities are things that need to be considered for maintaining health and preventing various diseases.

Many epidemiological studies have confirmed that physical activities can reduce the risk of aging or age-related morbidity, and mortality of any cause. Different type of physical activities can be done, however, to get the benefit some variables such as intensity and duration of the physical activities must be considered. High intensity physical activities (vigorous) might reduce the risk of death caused by coronary heart disease as much as $30 \%$, and lower the risk of death caused by stroke or osteoporosis by $25 \%$. The studies showed that we need to know whether the intensity of any undertaken physical activities had been sufficient to obtain maximum benefit.

Several methods and tools have been developed for measuring the intensity of physical activities. One of the methods for measuring physical activities deemed to be accurate and widely used is accelerometer. This article aims to discuss about accelerometer and its benefits for measuring physical activities.
\end{abstract}

Key words: accelerometer, physical activities.

\begin{abstract}
ABSTRAK
Berbagai penelitian menunjukkan bahwa terjadinya penyakit kronik di usia lanjut sangat dipengaruhi oleh gaya hidup tidak aktif atau sedentary yang dijalani oleh individu tersebut pada usia muda. Selain itu aktivitas fisik diketahui sangat bermanfaat mendukung pertumbuhan dan perkembangan yang optimal pada anak dan remaja. Olahraga dan akitivitas fisik adalah hal yang perlu diperhatikan dalam menjaga kesehatan dan mencegah berbagai macam penyakit.

Banyak penelitian epidemiologis telah memastikan bahwa aktivitas fisik dapat menurunkan risiko berbagai morbiditas yang berkaitan dengan usia atau penuaan serta risiko mortalitas akibat sebab apapun. Berbagai jenis aktivitas fisik dapat dilakukan namun untuk mendapatkan manfaatnya, beberapa variabel seperti intensitas dan durasi aktivitas fisik yang dilakukan, harus diperhatikan. Aktivitas fisik dengan intensitas yang cukup tinggi (vigorous) dapat menurunkan risiko kematian akibat penyakit jantung koroner sebanyak 30\%, atau penurunan risiko kematian akibat stroke atau osteoporosis sebesar $25 \%$. Penelitian tersebut menunjukkan bahwa kita perlu mengetahui apakah intensitas aktivitas aktivitas fisik yang dilakukan sudah mencukupi untuk mendapat kemanfaatan yang optimal

Berbagai metode dan alat yang telah dikembangkan dalam pengukuran intensitas aktivitas fisik. Salah satu metode penilaian aktivitas fisik yang dianggap akurat dan cukup banyak digunakan adalah akselerometer. Artikel ini bertujuan untuk membahas tentang accelerometer dan manfaatnya dalam menilai aktivitas fisik.
\end{abstract}

Kata kunci: accelerometer, aktivitas fisik. 


\section{PENDAHULUAN}

Semua orang ingin memiliki kesehatan. Menjadi sehat tidak hanya berarti berada dalam keadaan bebas dari penyakit, tetapi juga berarti memiliki wellness atau yang mungkin dapat diterjemahkan sebagai kesejahteraan. Seseorang dikatakan memiliki wellness bila individu tersebut memiliki kesejahteraan biologis maupun psikologis yang tergambar dari kualitas hidup dan perasaan sejahtera.

Seperti halnya berbagai hal dalam hidup ini, kesehatan bukanlah sesuatu yang diperoleh secara otomatis. Seseorang perlu berusaha untuk menjadi sehat dengan memiliki gaya hidup yang mendukung terciptanya kesehatan, seperti misalnya dengan menerapkan gaya makan yang sehat, memperhatikan masalah penanganan stres, dan memiliki aktivitas fisik yang rutin (Corbin et al, 2000).

Sekarang ini dengan semakin mudahnya akses terhadap berbagai informasi baik melalui media elektronik maupun internet, isu mengenai pentingnya melakukan aktivitas yang rutin mulai marak disoroti oleh masyarakat. Hal ini juga berkaitan dengan semakin meningkatnya usia harapan hidup sehingga jumlah populasi masyarakat dengan usia lanjut juga semakin mendominasi. Padahal seperti yang telah diketahui bersama usia lanjut memiliki kaitan yang sangat erat dengan berbagai penyakit kronik dan penurunan fungsi organ yang sangat mempengaruhi kualitas hidup. Berbagai penelitian pun telah menunjukkan bahwa terjadinya penyakit kronik di usia lanjut sangat dipengaruhi oleh gaya hidup tidak aktif atau sedentary yang dijalani oleh individu tersebut pada usia muda. Selain itu aktivitas fisik diketahui sangat bermanfaat mendukung pertumbuhan dan perkembangan yang optimal pada anak dan remaja (Sharratt \& Hearst, 2007). Oleh karena itu tidaklah salah bila aktivitas fisik dianggap sebagai hal yang sangat penting untuk diperhatikan.

Banyak penelitian epidemiologis telah memastikan bahwa aktivitas fisik dapat menurunkan risiko berbagai morbiditas yang berkaitan dengan usia atau penuaan serta risiko mortalitas akibat sebab apapun. Berbagai jenis aktivitas fisik dapat dilakukan namun untuk mendapatkan manfaatnya, beberapa variabel seperti intensitas dan durasi aktivitas fisik yang dilakukan, harus diperhatikan (Peterson et al, 2007). Dibutuhkan aktivitas fisik dengan intensitas yang cukup tinggi (vigorous) untuk dapat memperoleh manfaat penurunan risiko kematian akibat penyakit jantung koroner sebanyak 30\%, atau penurunan risiko kematian akibat stroke atau osteoporosis sebesar 25\% (Warburton et al, 2007). Dengan demikian pertanyaan selanjutnya adalah bagaimana kita dapat 
mengetahui apakah intensitas aktivitas fisik yang kita lakukan sudah mencukupi untuk dapat memperoleh manfaat yang optimal. Banyak metode dan alat yang telah dikembangkan dalam pengukuran intensitas aktivitas fisik. Salah satu metode penilaian aktivitas fisik yang dianggap akurat dan cukup banyak digunakan adalah accelerometer. Mengingat manfaatnya yang besar dalam penilaian aktivitas fisik, maka sebagai seorang ahli kesehatan olahraga adalah penting bagi kita untuk sungguh-sungguh memahami penggunaan accelerometer ini.

\section{KAJIAN PUSTAKA A. Aktivitas Fisik}

Aktivitas fisik adalah segala
gerakan tubuh yang dihasilkan oleh
kontraksi otot rangka dan meningkatkan pengeluaran energi. Pada dasarnya aktivitas fisik bersifat multi-dimensi dan memiliki berbagai bentuk atau domain (Corbin et al, 2000). Dimensi-dimensi aktivitas fisik mencakup frekuensi, durasi, intensitas, dan jenis. Sedangkan domain aktivitas fisik umumnya mencakup aktivitas fisik di waktu senggang, dalam pekerjaan (occupational), aktivitas transportasi dan berbagai aktivitas yang berkaitan dengan pekerjaan rumah. Pada anak-anak dan remaja dapat ditemukan pula beberapa domain lain yaitu aktivitas fisik di sekolah, di luar sekolah, dan aktivitas fisik di lingkungan khusus (Trost, 2007). Secara sederhana aktivitas fisik dapat dikelompokkan menjadi aktivitas fisik yang terjadi saat tidur, saat bekerja, dan saat waktu senggang. Selanjutnya aktivitas fisik di waktu senggang dapat dibagi lagi menjadi olahraga, latihan (exercise), pekerjaan rumah tangga, dan lain-lain (Caspersen et al, 1985). Berdasarkan jenisnya, aktivitas fisik juga dapat dibagi menjadi aktivitas fisik terstruktur dan tidak terstruktur seperti yang tampak dalam bagan berikut (Gambar 1).

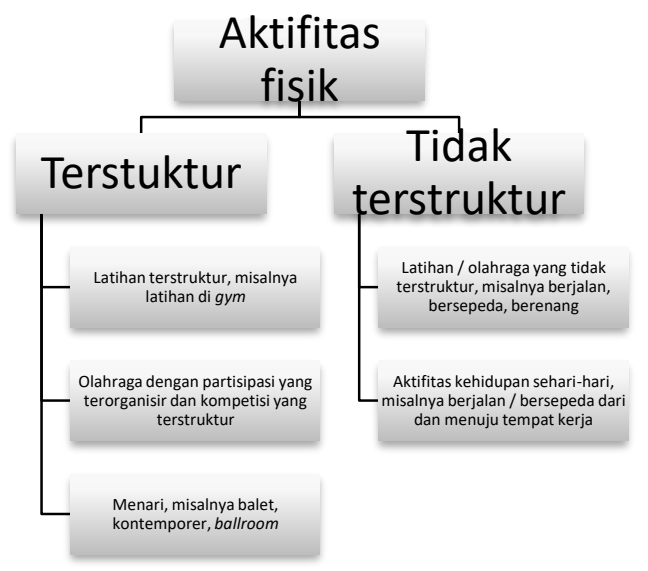

Gambar 1. Pembagian jenis aktivitas fisik (Pro-Active Central London, 2010

Dari segi kontraksi otot, perlu diketahui bahwa kontraksi otot memiliki aspek mekanik dan metabolik. Secara mekanik, kontraksi otot dapat dibagi menjadi kontraksi isometrik atau latihan statis dimana tidak terdapat pergerakan ekstremitas, dan kontraksi isotonik atau yang disebut sebagai latihan dinamis dimana terdapat pergerakan ekstremitas. Selain itu kontraksi otot dapat bersifat 
konsentrik yang disertai pemendekan serat otot, atau dapat pula bersifat eksentrik yang disertai pemanjangan serat otot. Selanjutnya secara metabolik kontraksi otot dapat dibagi menjadi kontraksi aerobik dan kontraksi anaerobik. Pembagian ini didasarkan pada ketersediaan oksigen untuk proses kontraksi dan hal ini ditentukan terutama oleh intensitas aktivitas yang dilakukan. Kontraksi aerobik adalah kontraksi yang terjadi saat oksigen tersedia, dan sebaliknya kontraksi anaerobik terjadi tanpa adanya oksigen. Pada dasarnya tidak ada aktivitasyang sungguh-sungguh dapat dikategorikan menjadi kontraksi statis atau dinamis secara eksklusif, ataupun menjadi aktivitas aerobik atau anaerobik. Sehingga aktivitas fisik biasanya dikelompokkan berdasarkan aspek yang lebih dominan (Heskell \& Kierman, 2007).

\section{B. Manfaat Pengukuran Aktivitas Fisik}

Aktivitas fisik merupakan faktor yang ditemukan sangat berkaitan dengan risiko terjadinya berbagai penyakit. Kurangnya aktivitas fisik menyebabkan meningkatnya risiko seseorang mengalami penyakit jantung iskemik, diabetes tipe 2 , kanker kolon, depresi atau kanker payudara. Bahkan meningkatnya aktivitas fisik dikatakan akan menurunkan risiko terjadinya kematian prematur (Gambar 2).

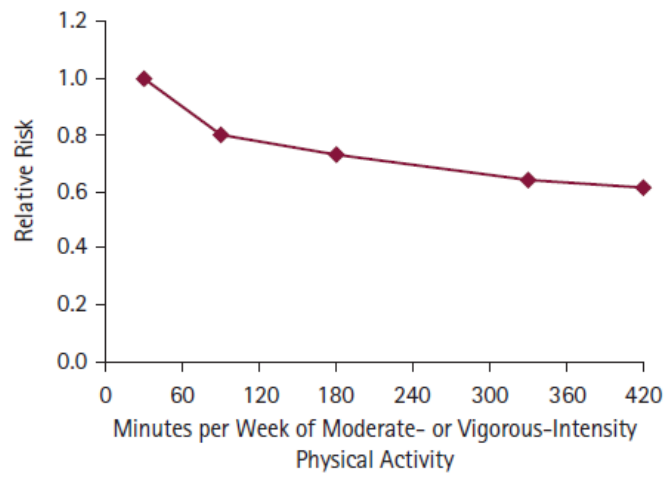

Gambar 2. Risiko terjadinya kematian prematur dibandingkan dengan durasi aktivitas fisik yang dilakukan (U.S. Department of Health and Human Services, 2008)

Walaupun telah banyak penelitian yang membuktikan hubungan tersebut, pada kenyataannya masih banyak orang yang hidup dengan gaya hidup tidak aktif. Secara global didapatkan $17 \%$ populasi hanya sedikit atau bahkan tidak melakukan aktivitas fisik sama sekali, dan terdapat $40 \%$ populasi yang melakukan aktivitas fisik dengan intensitas yang tidak cukup untuk memperoleh manfaat kesehatan (Maddison \& Mburchu, 2009).

Seperti yang telah disebutkan sebelumnya, tidak semua aktivitas fisik memberikan manfaat bagi kesehatan. Jenis dan dosis aktivitas fisik yang dilakukan merupakan faktor yang sangat menentukan (Peterson et al, 2007). Dengan melihat keadaan tersebut penilaian aktivitas fisik adalah hal yang sangat penting untuk dapat memantau aktivitas fisik yang dilakukan dan merancang intervensi yang sesuai untuk setiap individu (Macfarlane et al, 
2006). Selain itu pemberian informasi mengenai aktivitas fisik sehari-hari yang dilakukan, yaitu dalam hal jenis aktivitas fisik, durasi dan intensitas, kepada individu yang bersangkutan, diharapkan dapat menumbuhkan kesadaran individu tersebut tentang aktivitas fisik yang sehat. Informasi tersebut juga diharapkan dapat membantu memotivasi seseorang untuk tetap mempertahankan aktivitas fisik yang selama ini dilakukan untuk mencegah terjadinya berbagai masalah kesehatan akibat gaya hidup tidak aktif (Yin \& Goris, 2008). Selanjutnya penilaian aktivitas fisik diperlukan untuk menilai efektifitas intervensi yang telah diberikan kepada pasien untuk meningkatkan aktivitas fisik sehari-hari (Trost, 2007).

Beberapa manfaat lain dari penilaian aktivitas fisik secara akurat antara lain adalah juga untuk :

Penelitianselanjutnya yang dapat semakin memantapkan hubungan antara jenis dan dosis aktivitas fisik yang dibutuhkan dengan manfaat kesehatan yang diharapkan (Corder et al, 2008).

Mengidentifikasi faktor-faktor psikososial dan lingkungan yang mempengaruhi perilaku / kebiasaan aktivitas fisik(Trost, 2007).

\section{Metode-metode Pengukuran Aktivitas Fisik}

Terdapat sejumlah besar metode penilaian aktivitas fisik yang dapat digunakan. Secara umum berbagai metode ini dapat dikelompokkan menjadi metode subyektif dan metode obyektif. Namun metode subyektif maupun obyektif dapat dikombinasikan untuk memperoleh penilaian aktivitas fisik yang bersifat lebih menyeluruh (Corder et al, 2008).

\section{Metode Subyektif}

Metode penilaian aktivitas fisik secara subyektif dilakukan dengan penggunaan kuesioner, diari aktivitas fisik, ataupun dengan observasi langsung. Secara keseluruhan akurasi dari metode subyektif sangat tergantung pada kemampuan subyek untuk mengingat setiap aktivitas secara detail, serta pada pendapat dan persepsi subyek maupun peneliti (Trost, 2007).

a. Kuesioner dan Diari Aktivitas Fisik

Metode ini merupakan metode yang relatif tidak membutuhkan biaya yang mahal dan dapat diterapkan pada populasi berukuran besar. Oleh karena itu metode ini paling sering digunakan dalam penilaian aktivitas fisik. Namun demikian metode kuesioner memiliki keandalan(reliability) dan kesahihan (validity) yang rendah (Westerterp, 2009).

Berbagai kuesioner telah tersedia untuk dipakai sesuai dengan populasi target yang dituju, antara lain International 
Physical Activity Questionnaire (IPAQ), Physical Activity Recall (PAR), Habitual Activity Questionnaire (HAQ), Physical Activity Questionnaire for Older Children (PAQ-C), Physical Activity Questionnaire for Adolescent (PAQA),Physical Activity Scale for Elderly (PASE), The Rapid Assessment of Physical Activity (RAPA) dan lain-lain. ${ }^{12,14,16,17}$ Selain itu terdapat juga kuesioner yang menilai aktivitas fisik secara restrospektif dan kuantitatif (retrospective quantitative history), seperti misalnya Minnesota Leisure-time Physical Activity Questionnaire dan the Tecumseh Questionnaire. Kuesioner retrospektif kuantitatif ini biasanya mencakup jangka waktu yang cukup lama yaitu dapat mencapai 1 tahun, namun tentunya hal ini berarti responden memiliki beban yang lebih besar untuk mengingat aktivitas yang dilakukan di masa lampau (Haskell and Kiernan, 2000).

b. Observasi Langsung

Observasi langsung merupakan salah satu metode penilaian aktivitas fisik yang lebih unggul dibandingkan dengan metode lainnya sehingga metode ini sering digunakan sebagai kriteria validasi (Westerterp, 2009). Observasi langsung memungkinkan peneliti untuk mengidentifikasi berbagai faktor yang mempengaruhi kebiasaan aktivitas fisik (Trost, 2007). Namun metode ini memiliki kelemahan yaitu banyaknya waktu yang diperlukan peneliti, baik untuk menjalani pelatihan maupun untuk melaksanakan observasi (Badland, 2003). Tetapi sekarang ini penerapan metode observasi telah menggunakan sarana komputer (program video digital) yang dapat mempersingkat waktu yang dibutuhkan untuk observasi. Kehadiran peneliti / pengamat juga memperbesar kemungkinan terjadinya efek Hawthorne (Anderson, 2005). Selain itu terkadang subyek dapat merasa bahwa privasinya menjadi terusik. Dalam observasi langsung beban penilaian banyak terletak pada penilai / pengamat karena pengelompokan aktivitas yang diamati bersifat subyektif sesuai persepsi penilai (Corder, et al, 2008). Oleh karena itu metode ini kurang dapat digunakan untuk evaluasi dalam kondisi kehidupan seharihari (free living condition) dan lebih banyak digunakan untuk penilaian aktivitas fisik dalam situasi yang terkendali (controlled situations).

\section{Metode Obyektif}

Secara umum metode obyektif dapat dibagi lagi menjadi dua jenis, yaitu penilaian langsung menggunakan metode laboratorium, dan berbagai metode lapangan, misalnya dengan menggunakan pedometer, pemantauan denyut jantung, serta accelerometer (Badland, 2003). Berdasarkan dasar penilaian yang digunakan, berbagai metode obyektif juga 
dapat dikelompokkan menjadi tiga kategori (Schutz et al, 2001).

1. Penilaian berdasarkan jumlah energi yang dikeluarkan atau penggunaan oksigen, seperti misalnya dengan mengukur activity energy expenditure, activity related time equivalent, physical activity level, physical activity ratio, metabolic equivalent.

2. Penilaian berdasarkan pemantauan denyut jantung, seperti misalnya dengan menghitung net heart rate, physical activity ratio heart rate, physical activity level heart rate, activity-related Penilaian berdasarkan percepatan tubuh.

3. time equivalent, dan daytime physical activity level heart rate.

\section{a. Metode Doubly Labeled Water (DLW)}

Hingga saat ini metode DLW dianggap sebagai pemeriksaan yang paling akurat atau menjadi standard baku untuk menentukan total pengeluaran energi selama durasi yang cukup panjang pada kehidupan sehari-hari (Maddison \& Mhurchu, 2009). Dengan demikian bila metode ini digabungkan dengan pengukuran tingkat metabolisme dasar (Basal Metabolic Rate / BMR), tingkat pengeluaran energi akibat aktivitas fisik atau tingkat aktivitas fisik akan dapat diketahui (Plasqui et al, 2005). b. Metode Pengukuran Menggunakan Denyut Jantung

Alat pengukuran denyut jantung terdiri dari sabuk dada dan alat pendeteksi denyut jantung yang akan mengirimkan sinyal ke alat penerima sinyal berbentuk seperti jam tangan di pergelangan tangan. "Jam tangan" ini memiliki layar LCD kecil yang menampilkan gambar hati yang berkedip sesuai denyut jantung yang terdeteksi dan hasil perhitungan frekuensi denyut jantung (www.biotrainerusa.com).

Pemantauan denyut jantung merupakan metode yang relatif tidak membutuhkan biaya yang tinggi, namun terdapat beberapa kelemahan. Pertama, respon tubuh berupa perubahan frekuensi denyut jantung umumnya tidak terjadi segera setelah terjadinya perubahan aktivitas. Frekuensi denyut jantung dapat tetap meningkat untuk beberapa saat setelah seseorang berhenti berlari (Trost, 2007). Kedua, terdapat berbagai faktor perancu yang juga mempengaruhi hubungan antara frekuensi denyut jantung dan tingkat pengeluaran energi, seperti misalnya usia, ukuran tubuh, suhu lingkunan, keadaan emosional, status hidrasi, intake makanan dan kafein, kebiasaan merokok, dan banyaknya kelompok otot yang digunakan serta jenis kontraksi otot yang terjadi (Rowland, 2007). Selain kedua hal tersebut, terdapat pula dua kelemahan pemantauan denyut jantung secara teknis, yaitu dalam 
hal transmisi sinyal dan dalam hal kontak alat dengan kulit.

\section{c. Pedometer}

Pedometer merupakan alat pendeteksi gerakan yang memiliki perangkat inti berupa tuas horizontal yang dihubungkan dengan pegas ini akan merekam akselerasi dan deselerasi gerakan pada satu arah (Corner, 2008). Pedometer mekanik akan menghitung berapa kali ambang batas akselerasi tertentu dilewati, sedangkan pedometer piezoelektrik akan menghitung berapa kali garis nol dilewati oleh gelombang akselerasi. Dengan begitu pedometer yang dikenakan pada sabuk (di pinggang) atau di pergelangan kaki dapat memperkirakan jumlah langkah yang dilakukan (Corder et al, 2008).

Idealnya suatu metode penilaian aktivitas fisik harus dapat menyediakan penilaian ke-empat dimensi aktivitas fisik pada berbagai domain yang ada dengan kesahihan dan keandalan yang tinggi. Namun hingga saat ini tidak ada satu metode yang dapat memenuhi kriteria tersebut (Trost, 2007). Dengan demikian pada akhirnya dalam memilih metode mana yang akan digunakan terdapat tiga faktor yang perlu diperhatikan. Faktor pertama yaitu aspek aktivitas fisik mana yang hendak dinilai, misalnya bila peneliti hanya hendak menilai kebiasaan jalan kaki maka menggunakan pedometer saja sudah cukup, tetapi bila peneliti hendak mengetahui pola dan intensitas aktivitas fisik subyek, maka peneliti perlu menggunakan accelerometer. Yang kedua adalah karakteristik populasi target yang hendak dinilai, antara lain jenis kelamin dan usia subyek. Sebagai contohnya, seperti yang telah disebutkan secara sekilas di atas, terdapat berbagai kuesioner yang telah dikembangkan untuk berbagai kelompok umur, mulai dari untuk anak-anak, remaja hingga untuk lansia. Faktor yang ketiga adalah apakah penilaian akan dilakukan terhadap individu atau secara kelompok (Troiano, 2009). Selain itu, beberapa hal lain yang perlu diperhatikan dalam metode yang tepat adalah besar sampel, anggaran, sumber daya serta tenaga yang tersedia (Corder et al, 2008).

\section{Accelerometer}

Beberapa tahun terakhir penggunaan accelerometer dalam menilai aktivitas fisik menjadi semakin populer. Jumlah penelitian yang menggunakan accelerometerpada berbagai kelompok usia terus meningkat. Sekitar $63 \%$ penelitian tingkat aktivitas fisik pada anak-anak menggunakan accelerometer (Corderet al, 2008). Dengan melihat fakta tersebut dan mengingat pentingnya aktivitas fisik bagi kesehatan, adalah penting untuk memahami penggunaan accelerometer secara lebih detail.

\section{Prinsip kerja}


Accelerometer adalah suatu alat elektromekanik yang berfungsi mengubah gerakan fisik menjadi sinyal elektrik yang sebanding dengan kekuatan otot saat melakukan gerakan (Melanson \& Freedson, 1996). Pengubahan ini dilakukan dengan mengukur kekuatan akselerasi (Freedson, 2000). Yang dimaksud dengan akselerasi adalah tingkat perubahan kecepatan per satuan waktu yang dikur dalam satuan meter/detik ${ }^{2}\left(\mathrm{~m} / \operatorname{det}^{2}\right)$. Dalam pengukuran akselerasi juga dikenal satuan "g”, yaitu satuan akselerasi yang setara dengan tingkat gravitasi bumi di ketinggian permukaan air laut; Satu g adalah sebesar 9,81 m/det ${ }^{2}$ (www.usfirst.org). Terdapat dua jenis akselerasi yang diukur, yakni akselerasi yang bersifat statis dan akselerasi yang bersifat dinamis. Contoh dari akselerasi statis adalah kekuatan gravitasi yang secara konstan / terus-menerus memberi tarikan pada kaki seseorang. Dengan mengukur besarnya akselerasi statis akibat gravitasi, akan dapat diketahui sudut kemiringan suatu obyek / accelerometerterhadap bumi. Sedangkan akselerasi dinamis contohnya dialami saat accelerometer digerakkan atau digetarkan, sehingga dengan mengukur akselerasi dinamis, cara benda tersebut digerakkan akan dapat diketahui (www.dimensionengineering.com).

\section{Spesifikasi alat}

Secara umum terdapat berbagai jenis accelerometer berdasarkan jenis elemen sensor yang digunakan dan cara kerjanya (Westerterp, 2007), yaitu sebagai berikut :

a) Kapasitif

Dengan batang logam atau komponen elektronik kecil yang menghasilkan kapasitans, accelerometer kapasitif mendeteksi perubahan kapasitan listrik pada kondisi statis dan keadaan dinamis.

b) Hall effect

Accelerometer jenis ini mengukur perubahan voltase listrik yang disebabkan oleh perubahan medan magnet akibat pergerakan.

c) Magnetoresistif

Struktur accelerometer magnetoresistif hampir serupa dengan accelerometerhall effect namun accelerometer ini akan mengukur perubahan resistensi yang terjadi akibat medan magnet.

d) Transfer panas (heat transfer)

Pada accelerometer ini terdapat suatu sumber panas yang diletakkan di tengah-tengah rongga suatu substrat. Di keempat sisi rongga ditempatkan termoresistor yang akan mengalami perubahan resistensi karena gradien suhu yang tidak simetris akibat akselerasi yang menggerakkan sumber panas tersebut. 
e) Piezoresistif

Accelerometer piezoresistif bekerja dengan mendeteksi perubahan resistensi dari resistor silikon dan kemudian mengubahnya menjadi voltase yang besarnya sebanding dengan amplitudo dan frekuensi akselerasi pada massa kecil di dalam sensor. Jenis accelerometer ini juga berespon terhadap akselerasi yang konstan seperti misalnya akselerasi akibat gravitasi, namun umumnya membutuhkan sumber tenaga listrik eksternal.

f) Piezoelektrik

Accelerometer piezolektrik menggunakan suatu material, misalnya kristal piezoelektrik, yang akan menghasilkan potensial listrik saat mendapat stimulasi dari akselerasi yang terjadi. Dengan demikian accelerometer piezoelektrik tidak akan bereaksi terhadap akselerasi konstan seperti halnya accelerometer piezoresistif. Di lain pihak, accelerometer piezoelektrik tidak membutuhkan sumber tenaga listrik eksternal sehingga alat ini memiliki ukuran dan berat yang lebih kecil.

Selanjutnya terdapat beberapa aspek yang perlu diperhatikan dalam memilih suatu accelerometer, yaitu :

a. Rentang dinamika.
Yang dimaksud dengan rentang dinamika adalah amplitudo minimum dan maksimal akselerasi yang dapat diukur oleh accelerometer tanpa mengalami distorsi. Rentang dinamika ditulis dalam satuan "g". Untuk dapat menilai aktivitas fisik sehari-hari menggunakan accelerometer yang ditempatkan di pinggang, rentang dinamika $\quad-6 \quad$ hingga $6 \quad \mathrm{~g}$ sudah mencukupi.

b. Sensitifitas.

Sensitifitas accelerometer merujuk pada berapa besarnya perubahan sinyal yang terjadi akibat perubahan rangsangan / input akselerasi. Sensitiftas dinyatakan dalam satuan milivolt / g (mV/g).Jadi, semakin sensitif suatu accelerometer, semakin besar pula sinyal yang dihasilkan akibat sejumlah perubahan akselerasi. Dengan demikian accelerometer yang lebih sensitif akan menghasilkan penilaian yang lebih akurat.

c. Respon frekuensi.

Yang dimaksud dengan frekuensi respon adalah rentang frekuensi dimana accelerometer masih dapat mendeteksi gerakan dengan akurat. Frekuensi ini dinyatakan dalam satuan Hertz $(\mathrm{Hz})$. Oleh karena itu bila accelerometer ingin digunakan untuk menilai suatu pergerakan yang lambat (seperti misalnya saat menilai aktivitas fisik 
manusia), dapat digunakan accelerometer dengan respon frekuensi sekitar 0,3 - 35 Hz. Sedangkan bila accelerometer ingin digunakan untuk menilai suatu getaran atau suatu mesin berkecepatan tinggi, maka diperlukan yang memiliki frekuensi beberapa ratus $\mathrm{Hz}$.

d. Ukuran dan berat.

Ukuran alat sangat penting untuk diperhatikan supaya pemakaian accelerometer tidak mengganggu pola aktivitas fisik yang biasa dilakukan. Semakin kecil dan ringan suatu accelerometer akan meningkatkan kenyamanan subyek selama menggunakan accelerometer.

Selain berbagai faktor tersebut, faktor yang juga harus diperhatikan dalam memilih suatu accelerometer adalah sumbu atau aksis yang dinilai oleh accelerometer. Setiap accelerometer dirancang untuk mendeteksi input dari satu atau hingga tiga aksis (aksis anterior-posterior, mediolateral, dan vertikal). Accelerometer aksis tunggal (uniaksial) hanya akan mendeteksi akselerasi pada satu bidang, yaitu umumnya akselerasi di bidang vertikal (Schutz et al, 2001). Salah satu accelerometer uniaksial yang banyak digunakan dalam penilaian aktivitas fisik adalah ActiGraph GT1M (Trost, 2009). Accelerometer Actigraph GT1M menilai akselerasi pada bidang vertikal dengan rentang dinamika $0,05-2,5 \mathrm{~g}$ dan respon frekuensi $0,25 \quad-\quad 25 \quad \mathrm{~Hz}$ (www.theactigraph.com). Selain jenis uniaksial, terdapat pula accelerometer omdireksional yang dapat menilai akselerasi pada ketiga aksis namun paling sensitif terhadap bidang vertikal (Rowlands et al, 2007). Contoh accelerometer omnidireksional adalah accelerometer Actical dan Actiwatch. Actical dengan rentang dinamika $0,05-2 \mathrm{~g}$ dan respon frekuensi $\quad 0,35 \quad-\quad 3,5 \quad \mathrm{~Hz}$ merupakanaccelerometer yang dikatakan memiliki ukuran paling kecil (28 $\mathrm{x}$ (Rowlands et al, 2007) x $10 \mathrm{~mm}$ dengan berat 17 gram) dan tahan air. ${ }^{44}$ Jenis ketiga adalah accelerometer triaksial yang menilai akselerasi pada ketiga bidang, seperti misalnya accelerometer RT3 dan Tritrac (Trost, 2007).

Berbagai penelitian telah membandingkan penggunaan accelerometer uniaksial, omnidireksional, maupun triaksial dalam menilai aktivitas fisik. Beberapa di antaranya mendapati bahwa accelerometer uniaksial dapat memperkirakan secara akurat pengeluaran energi pada saat berjalan (Plasqui et al, 2005). Namun saat digunakan untuk menilai aktivitas fisik berlari, accelerometer uniaksial didapati memberikan hasil yang mendatar (plateau), terutama pada kecepatan di atas $10 \mathrm{~km} / \mathrm{jam}$. Hal ini berkaitan dengan unsur akselerasi 
horizontal yang lebih dominan dibandingkan dengan akselerasi vertikal saat berlari dengan kecepatan sedang hingga tinggi (Rowlands et al, 2007). Selain itu dengan mengingat bahwa accelerometer uniaksial hanya menilai satu aksis, dikatakan bahwa saat hendak menilai aktivitas fisik dimana berbagai jenis aktivitas fisik dapat terjadi adalah lebih cocok untuk menggunakan accelerometer triaksial.Akeselerometer triaksial juga dapat menilai pengeluaran energi pada tingkat aktivitas fisik tidak aktif (sedentary) dengan lebih baik (Westerterp, 1999).Terdapat hipotesis bahwa accelerometer uniaksial juga memiliki keterbatasan dalam menilai beberapa aktivitas tertentu, seperti misalnya berjalan mendaki bukit atau bersepeda (Trost, 2007). Namun secara keseluruhan masih didapatkan korelasi yang tinggi antara hasil pengukuran aktivitas fisik menggunakan accelerometer uniaksial dan omnidireksional (Rowlands et al, 2007).

\section{Cara penggunaan}

Dalam hal penggunaan accelerometer terdapat tiga hal utama yang perlu diperhatikan, yaitu lokasi pemakaian alat, epoch dan lamanya durasi pemantauan aktivitas fisik menggunakan accelerometer (Crouter \& Kerr, 2010).

\section{a. Lokasi Pemakaian Alat}

Accelerometer adalah alat yang berukuran cukup kecil dan dapat dikenakan di pinggang, pergelangan tangan maupun di pergelangan kaki menggunakan sabuk, kantung, penjepit ikat pinggang atau pita pergelangan kaki atau tangan. Pada dasarnya lokasi penggunaan accelerometer harus disesuaikan dengan jenis accelerometer dan tujuan penggunaan accelerometer. Secara umumpenempatan accelerometer di pinggang dikatakan sangat cocok untuk menilai aktivitas fisik sehari-hari dan memberikan perkiraan pengeluaran energi yang paling akurat (Berlin et al, 2006). Namun karena accelerometer ditempatkan di pinggul, maka jika subyek hanya menghentakhentakkan kaki ke lantai saat duduk, accelerometer tidak akan mendeteksi pergerakan tersebut (Trost et al, 2005). Mengenai pengaruh jenis accelerometer terhadap penentuan lokasi penggunaan accelerometer, terdapat penelitian yang mengatakan bahwa tidak ada perbedaan yang bermakna ketika hasil penilaian accelerometer dan hasil pemeriksaan kalorimetri indirek dibandingkan, baik untuk accelerometer uniaksial dan triaksial yang ditempatkan di pergelangan tangan, pinggul ataupun punggung bagian bawah (Westerterp, 2009). Tetapi penelitian yang membandingkan antara accelerometer uniaksial dan omnidireksional yang ditempatkan di pinggul dan tungkai bawah pada anak-anak mendapatkan bahwa tidak terdapat perbedaan hasil pengukuran 
aktivitas antara kedua lokasi tersebut untuk accelerometer omnidireksional, sedangkan untuk accelerometer uniaksial ditemukan perbedaan hasil (Berlin et al, 2006).

Beberapa penelitian juga membandingkan antara penempatan accelerometer di pinggul dan di punggung bagian bawah, baik pada orang dewasa maupun anak-anak. Hasilnya didapatkan bahwa tidak didapatkan perbedaan jumlah hitungan aktivitas / menit yang bermakna antara accelerometer yang ditempatkan di pinggul dan di punggung. Namun accelerometer yang diletakkan di punggung memberikan hasil hitungan aktivitas/menit yang lebih rendah secara bermakna untuk pengukuran aktivitas fisik tingkat sedang pada anak-anak dan tingkat rendah pada orang dewasa (Crouter \& Kerr, 2010). Selain itu penempatan accelerometer di sisi kiri atau kanan panggul juga ditemukan tidak mempengaruhi hasil penilaian aktivitas fisik yang dilakukan (McClain et al, 2007).

Lokasi penempatan accelerometer juga berhubungan dengan tingkat kenyamanan subyek. Pada penelitian yang membandingkan penempatan accelerometer di atas krista illiaka kanan dan di atas kaput fibula kanan pada anakanak, mendapatkan bahwa subyek merasa kurang nyaman dengan penempatan accelerometer di tungkai bawah. Accelerometer yang ditempatkan di tungkai bawah juga dirasakan lebih mudah merosot dan jatuh (Puyau et al, 2002). Saat accelerometer digunakan untuk menilai aktivitas fisik pada individu yang memiliki keterbatasan fisik, penempatan alat juga menjadi hal yang sangat penting untuk dipertimbangkan. Pada penelitian yang dilakukan pada populasi pasien stroke memang tidak ditemukan adanya perbedaan hasil penilaian aktivitas fisik saat accelerometer ditempatkan di sisi panggul yang mengalami paresis maupun yang tidak mengalami paresis. Padahal seperti yang telah diketahui bersama individu dengan stroke umumnya memiliki kecepatan berjalan yang lambat dan cara berjalan (gait) yang tidak simetris (Rand et al, 2009). Di lain pihak, cara penempatan alat perlu diperhatikan. Misalnya bila accelerometer hendak digunakan untuk menilai aktivitas fisik pada individu dengan gangguan penglihatan atau defisit neurologis. Mungkin mengencangkan atau melepaskan sabuk accelerometer dapat menjadi sesuatu yang sulit untuk dilakukan, sehingga adalah lebih mudah bila penempatan accelerometer menggunakan kantung atau penjepit ikat pinggang (Berlin et al, 2006).

\section{Epoch}

Accelerometer akan menghitung frekuensi aktivitas fisikyang dilakukan dalam setiap interval waktu yang telah 
ditetapkan sebelumnya oleh pengguna accelerometer. Interval waktu ini dikenal dengan sebutan epoch (Corder et al, 2009). Penetapan durasi epoch merupakan hal yang sangat penting untuk diperhatikan dan harus disesuaikan dengan usia subyek dan kapasitas memori accelerometer yang digunakan.

Idealnya durasi epoch yang digunakan tentunya sesingkat mungkin karena data hitungan frekuensi aktivitas fisik dari epoch yang kecil selalu dapat digabungkan bila penilaian ingin dilakukan dalam kerangka waktu yang lebih panjang, namun tidak dapat dilakukan sebaliknya (Corder et al, 2009). Saat menilai aktivitas fisik populasi dewasa umumnya menggunakan durasi epoch selama 1 menit. Tetapi dalam menilai aktivitas fisik pada anak-anak, durasi epoch 1 menit tidak dapat digunakan karena akan memberikan hasil yang lebih rendah dibandingkan dengan yang sesungguhnya (Trost et al, 2005). Perlu diingat bahwa aktivitas fisik anakanak bersifat sporadik dengan banyak episode aktifitas fisik intensitas tinggi yang berlangsung singkat (Stone et al, 2005). Suatu penelitian observasional menemukan bahwa aktifitas fisik dengan intensitas tinggi pada anak-anak rata-rata hanya berlangsung selama 3 detik (Baily et al, 1996). Masih terdapat kontroversi tentang berapa tepatnya durasi epoch yang dianjurkan untuk penilaian aktivitas fisik pada anak-anak. Namun para ahli setuju bahwa semakin pendek durasi epoch yang digunakan, hasilnya akan semakin baik. Banyak penelitian yang menyarankan untuk menggunakan durasi epoch yang lebih kecil dari 10 detik, atau bahkan selama 5 detik (Stone et al, 2009).

Seperti yang telah disebutkan sebelumnya, penetapan durasi epoch juga sangat ditentukan oleh faktor teknis yaitu kapasitas penyimpanan data yang selanjutnya akan berkaitan dengan durasi pemantauan aktivitas fisik. Sekarang ini beberapa accelerometer telah memiliki kapasitas penyimpanan data yang cukup besar untuk dapat merekam data dengan panjang epoch 5 detik selama seminggu penuh (Corder et al, 2008). Namun tidak semua accelerometer memiliki daya simpan yang demikian besar (Tabel 8). Akibatnya peneliti seringkali menyesuaikan durasi epoch dengan kemampuan accelerometer serta durasi pemantauan aktivitas fisik yang hendak dicapai (Rawlands et al, 2007).

Tabel 1. Contoh panjang epoch dan durasi pemantauan aktivitas fisik maksimal pada Actiwatch dan Actical.

\begin{tabular}{|c|c|c|c|c|}
\hline \multirow{3}{*}{$\begin{array}{l}\text { Durasi } \\
\text { epoch }\end{array}$} & \multirow{3}{*}{$\begin{array}{c}\text { Jumlah } \\
\text { epoch }\end{array}$} & \multicolumn{3}{|c|}{ Durasi pemantauan maksimal } \\
\hline & & \multicolumn{2}{|c|}{ Actiwatch } & \multirow[b]{2}{*}{ Actical } \\
\hline & & $\begin{array}{c}\text { Hanya saat } \\
\text { terjaga }\end{array}$ & $\begin{array}{c}\text { Sepanjang } \\
\text { hari }\end{array}$ & \\
\hline $\begin{array}{c}15 \\
\text { detik }\end{array}$ & $\begin{array}{c}\text { Le } \\
\text { Masurier 1, } \\
\text { 2006)60 }\end{array}$ & 22,7 hari & 7,5 hari & 11 hari \\
\hline $\begin{array}{c}30 \\
\text { detik }\end{array}$ & 2880 & 45,5 hari & 15,1 hari & 22 hari \\
\hline $\begin{array}{c}1 \\
\text { menit }\end{array}$ & 1440 & 91 hari & 30,3 hari & 44 hari \\
\hline
\end{tabular}




\section{b. Durasi Pemantauan Aktivitas Fisik}

Berbagai penelitian telah menganjurkan bahwa durasi pemantauan selama 4 hingga 12 hari dibutuhkan untuk melakukan penilaian aktivitas fisik seharihari yang akurat menggunakan accelerometer. Pada populasi dewasa, umumnya durasi pemantauan selama 7 hari sudah mencukupi untuk memperoleh hasil yang akurat. Sedangkan pada anak-anak durasi pemantauan yang dianjurkan adalah selama 4 hingga 5 hari, dan pada usia remaja selama 8 hingga 9 hari. Namun secara teknis, dalam menentukan durasi pemantauan aktivitas fisik, kapasitas penyimpanan data dan daya tahan baterai juga sangat perlu diperhatikan Berlin et al, 2006).

\section{c. Hal-hal lain yang perlu Diperhatikan}

Isu lain yang perlu diperhatikan dalam penggunaan accelerometer adalah jumlah accelerometer dalam sekali penilaian aktivitas fisik. Berbagai penelitian telah menunjukkan penggunaan lebih dari satu accelerometer pada satu subyek hanya akan sedikit menambah akurasi perkiraan pengeluaran energi. Namun penambahan akurasi tersebut tidak sebanding dengan peningkatan biaya, waktu dan tenaga yang harus dikeluarkan oleh peneliti bila menggunakan lebih dari satu accelerometer pada satu subyek (Puyau et al, 2002).
Dalam melakukan penilaian aktivitas fisik seringkali juga ditemukan masalah kepatuhan subyek dalam menggunakan accelerometer, terutama pada subyek berusia anak-anak atau remaja. Instruksi perlu diberikan secara jelas dan juga diperlukan dukungan dari pihak lain, seperti orang tua, guru, pelatih dan lainlain. Pemberian insentif atau "imbalan" kepada subyek yang memakai alat sesuai instruksi juga perlu dipertimbangkan (Crouter \& Kerr, 2010). Suatu penelitian yang meneliti mengenai kemampulaksanaan penilaian aktivitas fisik pada 282 anak usia remaja di suatu sekolah, menggunakan beberapa cara untuk meningkatkan kepatuhan anak-anak menggunakan accelerometer dan mengembalikan accelerometer kepada peneliti pada akhir masa penilaian. Beberapa cara tersebut adalah dengan meminta guru mendemonstrasikan cara pemakaian accelerometer yang benar dan memberikan instruksi yang jelas secara lisan maupun tertulis kepada subyek. Guru sekolah tersebut juga diminta untuk mengunjungi rumah subyek di tengah masa penilaian aktivitas fisik untuk mengingatkan subyek memakai alat dan mengembalikannya di akhir penilaian. Terakhir, subyek yang mengembalikan alat tepat waktu diberikan hadiah tiket menonton bioskop. Dengan berbagai cara ini tetap hanya $50 \%$ subyek yang memiliki 
data accelerometer yang lengkap selama 7 hari, dan masih terdapat sekitar $10 \%$ subyek yang mengembalikan alat secara terlambat (Treuth et al, 2007).

\section{d. Kalibrasi}

Hasil pengukuran accelerometer dinyatakan dalam satuan jumlah aktivitas fisik per satuan waktu (hitungan/menit atau counts/minute). Hasil ini spesifik untuk tiap jenis ataupun merk accelerometer sehingga tidak dapat dibandingkan satu sama lain. Untuk dapat dibandingkan satu sama lain maka satuan tersebut diubah atau dikalibrasi menjadi berbagai satuan pengeluaran energi menggunakan berbagai rumus (Rowlands et al, 2007). Dalam hal kalibrasi ini perlu diingat bahwa tingkat pengeluaran energi seseorang juga dipengaruhi oleh faktor massa tubuh dan komposisi tubuh (Plasqui et al, 2005). Selain itu usia seseorang juga akan mempengaruhi besarnya tingkat metabolisme basal (resting metabolic rate) yang selanjutnya ikut menentukan penghitungan intensitas aktivitas fisik dalam satuan MET maupun penghitungan pengeluaran energi akibat aktivitas (Trost et al, 2005). Oleh karena itu setiap rumus ataupun nilai batas hitungan/menit untuk setiap jenis atau tingkatan aktivitas fisik bersifat spesifik untuk setiap kelompok umur (Le Masurier , 2006).

\section{1) Kalibrasi pada Anak dan Remaja}

Pada anak-anak ditemukan berbagai rumus yang mengkalibrasi hasil perhitungan aktivitas fisik menggunakan accelerometer menjadi berbagai satuan

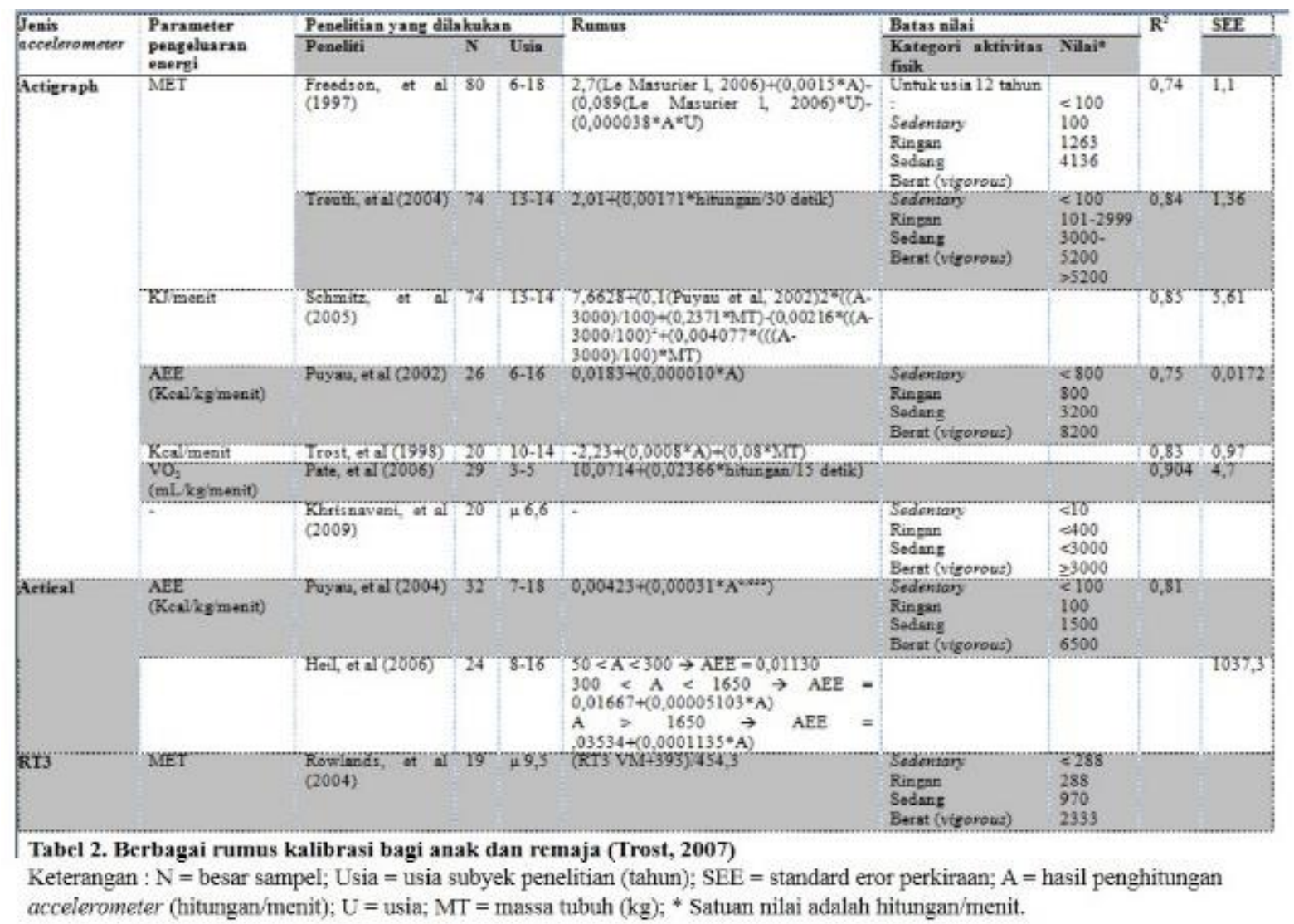


pengeluaran energi seperti yang tampak dalam tabel Tabel 2.

\section{2) Kalibrasi pada Dewasa}

Berbagai penelitian juga telah dilakukan untuk menciptakan rumus ataupun menetapkan nilai batas tingkat aktivitas fisik berdasarkan hasil penilaian accelerometer pada populasi dewasa. Seluruh penelitian dengan accelerometer uniaksial menggunakan Actigraph. Salah satu penelitian menggunakan Actigraph pada (Trost et al, 2005) orang dewasa sehat di Amerika (rata-rata usia 35 thn) berusaha untuk menetapkan rumus untuk mengkalibrasi hasil hitungan aktivitas/menit menjadi satuan pengeluaran energi MET dengan memperhitungkan koefisien varians hasil penghitungan akseleromter setiap 10 detik (Tabel 10) (Caspersen et al, 1985).

Selain penelitian di atas, terdapat banyak penelitian lain yang menggunakan

Actigraph untuk menghitung pengeluaran energi dalam berbagai satuan (Tabel 3).

Selain menggunakan Actigraph, penelitian pada populasi dewasa juga telah dilakukan menggunakan accelerometer triaksial Tritrac dan Tracmor. Dengan menggunakan Tritrac, ditetapkan tiga tingkatan aktivitas fisik dengan nilai batas $650-1.210$ hitungan/menit untuk aktivitas fisik tingkat ringan, $1.211-2.893$ hitungan/menit untuk aktivitas fisik tingkat sedang, serta $\geq 2.894$ hitungan/menit untuk aktivitas fisik tingkat berat (Nichols et al, 1999).

Penelitian pada 29 subyek individu berusia 18-40 tahun dengan menggunakan accelerometer Tracmor juga dilakukan untuk membentuk rumus perhitungan total pengeluaran energi (Total Energy Expenditure / TEE) dan jumlah pengeluaran energi akibat aktivitas fisik (AEE) Rumus dibentuk dengan metode Tabel 3. Kalibrasi hasil penilaian Actigraph pada orang dewasa (Caspersen et al, 1985).

\begin{tabular}{|c|c|c|c|c|}
\hline $\begin{array}{c}\text { Hasil pengukuran } \\
\text { accelerometer } \\
\text { (hitungan/menit) }\end{array}$ & $\begin{array}{c}\text { Koefisien } \\
\text { variasi }\end{array}$ & $\begin{array}{l}\text { Besar pengeluaran energi } \\
\text { (MET) }\end{array}$ & $\mathbf{R}^{2}$ & SEE \\
\hline$\leq \mathbf{5 0}$ & - & $1 \mathrm{MET}$ & & \\
\hline \multirow[t]{2}{*}{$>\mathbf{5 0}$} & $\leq 10$ & $\begin{array}{c}2,379833^{*}\left[\exp \left(0,00013529^{*} \text { hit }\right.\right. \\
\text { ungan/menit })]\end{array}$ & 0,701 & $\begin{array}{c}0, \text { (Rowlands et al, } \\
2007) 5\end{array}$ \\
\hline & 0 atau $>10$ & 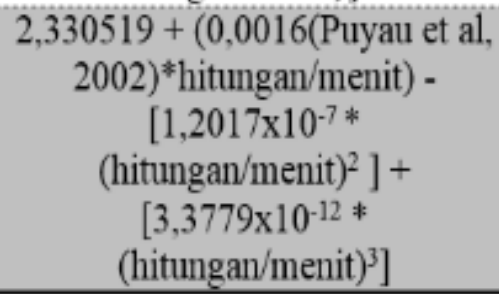 & 0,854 & 0,94 \\
\hline
\end{tabular}


analisis regresi multipel dan memperhitungkan faktor-faktor lainnya yang mempengaruhi pengeluaran energi, seperti faktor usia, berat badan, tinggi Keterangan : SMR = Sleeping Metabolic Rate (MJ/hari); A = kilo hitungan/hari; Usia (tahun); $\mathrm{BB}=$ berat badan $(\mathrm{kg}) ; \mathrm{TB}=$ tinggi badan (m); FFM = Fat Free Mass (kg); FM $=$ Fat Mass $(\mathrm{kg})$.

badan, dan lain-lain (Plasqui et al, 2005).

Tabel 4. Berbagai rumus penghitungan pengeluaran energi dari hasil penghitungan Actigraph +ada populasi dewasa (Crouter \& Kerr, 2010).

\begin{tabular}{|c|c|c|c|c|}
\hline Peneliti & $\mathbf{n}$ & Rumus & $\mathbf{R}^{2}$ & SEE \\
\hline \multicolumn{5}{|l|}{ Penghitungan MET } \\
\hline Freedson et al (1998) & 50 & $1,439008+(0,000795 * A)$ & 0,82 & 1,12 \\
\hline Hendelman et al $(2000)$ & 25 & $1,602+(0,000638 * A)$ & 0,59 & 0,89 \\
\hline Hendelman et al (2000) & 25 & $2,922+(0,000409 * \mathrm{~A})$ & 0,35 & 0,96 \\
\hline Swartz et al $(2000)$ & 70 & $2,606+(0,0006863 * A)$ & 0,32 & 1,16 \\
\hline Leenders et al (2003) & 28 & $2,24+\left(0,0006^{*} \mathrm{~A}\right)$ & 0,74 & 0,53 \\
\hline Yngve et al (2003) & 28 & $1,136+(0,0008249 * A)$ & 0,85 & 1,14 \\
\hline Yngve et al (2003) & 28 & $0,751+(0,0008198 * A)$ & 0,86 & 1,1 \\
\hline Heil et al (2003) & 58 & $\begin{array}{c}(0,00171 * \mathrm{~A})+(1,9(\text { Le Masurier } 1, \\
\left.2006)^{*} \mathrm{~TB}\right)-\left(0,000631^{*} \mathrm{~A} \text { TB }\right)- \\
1,883\end{array}$ & 0,71 & 0,59 \\
\hline Brooks et al (2005) & 72 & $2,32+(0,000289 * A)$ & 0,51 & 0,44 \\
\hline Brooks et al (2005) & 72 & $3,33+\left(0,000370^{\circ} \mathrm{A}\right)-(0,012 * \mathrm{BB})$ & 0,61 & 0,4 \\
\hline \multicolumn{5}{|l|}{ Perhitungan Kcal/menit } \\
\hline $\begin{array}{l}\text { Pergamaan dari produsen alat } \\
\text { (netEE) }\end{array}$ & & $0,0000191 \% A * B B$ & & \\
\hline Freedson et al (1998) & 35 & $\begin{array}{c}(0,00094 * A)+(0,13 \text { (Puyau et al, } \\
\left.2002)^{8} \mathrm{BB}\right)-7,37418\end{array}$ & 0,82 & 1,4 \\
\hline Brooks et al (2005) & 72 & $3,377+(0,000370 * A)$ & 0,17 & 0,95 \\
\hline Brooks et al (2005) & 72 & $\begin{array}{c}(0,000452 * \mathrm{~A})+(0,051 * \mathrm{BB})- \\
0,774\end{array}$ & 0,77 & 0,5 \\
\hline \multicolumn{5}{|l|}{$\begin{array}{l}\text { Penghitungan } \mathrm{VO}_{2} \\
(\mathrm{~mL} / \mathrm{kg} / \text { menit })\end{array}$} \\
\hline Nichols et al (2000) & 60 & $\begin{array}{c}6,0(\text { Le Masurier } 1,2006) 359 \\
\left(0,002545^{*} \mathrm{~A}\right)\end{array}$ & 0,89 & 3,72 \\
\hline
\end{tabular}

Keterangan : $\mathrm{A}=$ hasil pengukuran Actigraph (hitungan/menit); $\mathrm{TB}=$ tinggi badan $(\mathrm{cm}) ; \mathrm{BB}=$ bera. badan (kg).

Tabel 6. Rumus penghitungan total pengeluaran energi berdasarkan hasil pengukuran accelerometer Tracmor (Plasqui et al, 2005).

\begin{tabular}{|c|c|c|c|}
\hline $\begin{array}{l}\text { Nilai } \\
\text { MET }\end{array}$ & $\begin{array}{c}\text { Freedson et } \\
\text { al (1998) }\end{array}$ & $\begin{array}{l}\text { Hendelman } \\
\text { et al (2000) }\end{array}$ & $\begin{array}{c}\text { Swartz et al } \\
(2000)\end{array}$ \\
\hline$<3$ & $0-1951$ & $0-190,6$ & $\begin{array}{c}0-(\text { Le } \\
\text { Masurier } 1, \\
2006) 3\end{array}$ \\
\hline $3-6$ & $\begin{array}{c}1952-(\mathrm{Le} \\
\text { Masurier } 1 \text {, } \\
\text { 2006)24 }\end{array}$ & $\begin{array}{l}190,7- \\
7525,7\end{array}$ & $\begin{array}{c}(\text { Le } \\
\text { Masurier 1, } \\
\text { 2006)4 - } \\
4944\end{array}$ \\
\hline $7-8$ & $\begin{array}{c}(\text { Le } \\
\text { Masurier 1, } \\
\text { 2006)25 - } \\
9497\end{array}$ & $\begin{array}{c}7525,8- \\
\text { 1(Trost et al, } \\
\text { 2005)60,5 }\end{array}$ & $4945-9317$ \\
\hline$\geq 9$ & $\geq 9498$ & $\begin{array}{c}\geq 1 \text { (Trost et } \\
\text { al, 2005)60,6 }\end{array}$ & $\geq 9318$ \\
\hline
\end{tabular}


Tabel 6. Rumus penghitungan total pengeluaran energi berdasarkan hasil pengukuran accelerometer Tracmor (Plasqui et al, 2005).

\begin{tabular}{cccc}
\hline No. & Rumus & R $^{2}$ & SEE \\
\hline $\mathbf{1}$ & $-7,98+\left(2,58^{*} \mathrm{SMR}\right)+\left(8,(\right.$ Le Masurier 1,2006$\left.) \times 10^{-3} * \mathrm{~A}\right)$ & 0,9 & 0,74 \\
$\mathbf{2}$ & $-11,18-\left(0,11^{*} \mathrm{Usia}\right)+(0,13 * \mathrm{BB})+(7,69 * \mathrm{~TB})+\left(9,35 \times 10^{-3} * \mathrm{~A}\right)$ & 0,83 & 1 \\
$\mathbf{3}$ & $-0,63-\left(8,47 \times 10^{-2} *\right.$ Usia $)+(0,21 * \mathrm{FFM})+\left(6,89 \times 10^{-2} * \mathrm{FM}\right)+\left(6,47 \times 10^{-3} * \mathrm{~A}\right)$ & 0,9 & 0,77 \\
\hline
\end{tabular}

Keterangan : SMR = Sleeping Metabolic Rate $(\mathrm{MJ} /$ hari); $\mathrm{A}=$ kilo hitungan/hari; Usia (tahun); $\mathrm{BB}=$ berat badan $(\mathrm{kg}) ; \mathrm{TB}=$ tinggi badan $(\mathrm{m}) ; \mathrm{FFM}=$ Fat Free Mass $(\mathrm{kg}) ; \mathrm{FM}=$ Fat Mass $(\mathrm{kg})$.

Tabel 7. Rumus penghitungan pengeluaran energi akibat aktivitas fisik berdasarkan hasil pengukuran accelerometer Tracmor (Plasqui et al, 2005)

\begin{tabular}{|c|c|c|c|}
\hline No. & Rumus & $\mathbf{R}^{2}$ & SEE \\
\hline 1 & $\begin{array}{c}-8,11-\left(6,65 \times 10^{-2} * \text { Usia }\right)+\left(7,14 \times 10^{-2} * \mathrm{BB}\right)+\left(3,(\text { Puyau et al, } 2002)^{*} \mathrm{~TB}\right)+\left(7,92 \times 10^{-3} *\right. \\
\text { A) }\end{array}$ & 0,81 & 0,7 \\
\hline 2 & $\begin{array}{c}-3,47-\left(5,52 \times 10^{-2} * \text { Usia }\right)+\left(0,11^{*} \mathrm{FFM}\right)+\left(4,13 \times 10^{-2} * \mathrm{FM}\right)+\left(6,(\text { Trost et al, } 2005) \times 10^{-}\right. \\
3 * \mathrm{~A})\end{array}$ & 0,86 & 0,59 \\
\hline
\end{tabular}

Keterangan : $\mathrm{SMR}=$ Sleeping Metabolic Rate $(\mathrm{MJ} /$ hari); $\mathrm{A}=$ kilo hitungan/hari; Usia (tahun); $\mathrm{BB}=$ berat badan $(\mathrm{kg}) ; \mathrm{TB}=$ tinggi badan (m); FFM = Fat Free Mass (kg); FM = Fat Mass (kg).

\section{e. Aplikasi}

Penggunaan accelerometer untuk memantau aktivitas fisik telah sangat berkembang untuk berbagai indikasi. Pada dasarnya accelerometer sangat bermanfaat untuk mengetahui tingkat aktivitas fisik seseorang serta menilai pengaruh intervensi gaya hidup terhadap meningkatnya aktivitas fisik (Schutz, 2001). Banyak peneliti juga menggunakan accelerometer untuk menilai aktivitas fisik pada pelajaran olahraga maupun untuk melakukan validasi berbagai sarana pengukuran aktivitas fisik lain dalam menilai aktivitas fisik pada pelajaran olahraga (Le Masurier , 2006). Dalam hal ini, seperti yang telah disebutkan sebelumnya, masalah kepatuhan siswa mengenakan accelerometer perlu mendapat perhatian lebih (Treuth et al, 2007).

Di negara berkembang sekitar sepertiga orang berusia 65 tahun atau lebih mengalami jatuh setiap tahunnya. Kejadian jatuh pada orang lanjut usia merupakan yang paling sering menyebabkan diperlukannya rawat inap. Oleh karena itu banyak peneliti telah menggunakan untuk mengidentifikasi risiko jatuh pada individu lanjut usia (Lovell, 2008). Accelerometer juga dikembangkan sebagai alat pendeteksi terjadinya jatuh, yaitu dengan melekatkan accelerometer pada jaket / rompi khusus. Alat deteksi jatuh didapatkan memiliki sensitivitas sebesar $98,75 \%$ dan spesifisitas 98,6\% dalam membedakan kejadian jatuh dengan aktivitas fisik sehari-hari (Bourke et al, 2008).

Populasi khusus lain yang dapat terbantu dengan pemanfaatan akseleromter adalah pasien paska-stroke. Kejadian stroke akan mempengaruhi fungsi kognitif, bahasa, persepsi, sensorik maupun kemampuan motorik, dan banyak individu yang melaporkan mengalami keterbatasan fungsional paska stroke. Oleh karena itu 
dibutuhkan program rehabilitasi yang optimal, yaitu program yang didasarkan pada penilaian klinis kemampuan motorik pasien. Accelerometer merupakan sarana penilaian kemampuan motorik pasien paska stroke secara obyektif yang telah terbukti memiliki keandalan yang baik (Bonato, 2008). Selain untuk menyusun program rehabilitasi yang optimal, penilaian aktivitas fisik pada individu paska stroke juga dapat digunakan untuk menilai keberhasilan program rehabilitasi membantu pasien paska stroke untuk kembali berinteraksi dengan masyarakat secara normal (Rand et al, 2009).

\section{f. Kelebihan dan kekurangan}

Ukuran accelerometer yang kecil memungkinkan subyek memakai accelerometer tanpa merasa terganggu. Tetapi dibandingkan dengan observasi langsung accelerometer tentunya akan memberikan beban yang lebih ringan bagi peneliti. Accelerometer seringkali dibandingkan dengan alat pendeteksi gerak lain yang juga banyak digunakan, yaitu pedometer (Tabel 8). Accelerometer memang lebih mahal dan membutuhkan perangkat eksternal (seperti misalnya komputer) namun accelerometer memberikan informasi yang lebih mendetail mengenai aktivitas fisik, terutama mengenai intensitas aktivitas fisik yang dilakukan (Tudor et al, 2001). Selain itu accelerometer juga dilengkapi dengan jam internal dan kemampuan untuk menyimpan data yang memungkinkan peneliti untuk mengetahui pola aktivitas fisik sehari-sehari (Schutz et al, 2001). Pada suatu penelitian yang membandingkan antara accelerometer uniaksial dan pedometer juga didapatkan bahwa accelerometer dapat menghitung jumlah langkah dengan lebih baik dibandingkan pedometer saat individu tersebut berjalan dengan kecepatan lambat (54 m/menit). Namun dari penelitian tersebut juga ditemukan bahwa accelerometer uniaksial tampaknya memiliki validitas yang lebih rendah daripada pedometer saat digunakan untuk menilai aktivitas fisik seseorang saat sedang mengendarai kendaraan bermotor ( Le Masurier \& Tudor-Locke, 2003).

Tabel 8. Karakteristik askselerometer dan pedometer.

\begin{tabular}{|c|c|c|}
\hline Karakteristik & Pedometer & Accelerometer \\
\hline Biaya & $\begin{array}{l}\text { Rendah }(\$ 10- \\
\$ 200)\end{array}$ & $\begin{array}{l}\text { Menengah } \\
\text { hingga tinggi } \\
(\$ 300-\$ 600)\end{array}$ \\
\hline Keluaran utama & Langkah & Hitungan \\
\hline \multicolumn{3}{|l|}{ Aktivitas } \\
\hline Jenis & $\begin{array}{l}\text { Berjalan } \\
\text { (ambulatory) }\end{array}$ & $\begin{array}{l}\text { Ekstremitas } \\
\text { bawah dan } \\
\text { batang tubuh }\end{array}$ \\
\hline Frekuensi & Tidak diketahui & Diketahui \\
\hline Durasi & Tidak diketahui & Diketahui \\
\hline Intensitas & Tidak diketahui & Diketahui \\
\hline Beban bagi subyek & Rendah & Rendah \\
\hline Beban bagi peneliti & Rendah & Sedang \\
\hline Perolehan data & Ditulis tangan & $\begin{array}{l}\text { Menggunakan } \\
\text { komputer }\end{array}$ \\
\hline Penempatan alat & Pinggang & $\begin{array}{l}\text { Pinggang, } \\
\text { pergelangan } \\
\text { tangan, } \\
\text { pergelangan } \\
\text { kaki }\end{array}$ \\
\hline $\begin{array}{l}\text { Pengaruh obesitas } \\
\text { sentral terhadap } \\
\text { penilaian aktivitas } \\
\text { fisik }\end{array}$ & Ada & $\begin{array}{l}\text { Mungkin ada, } \\
\text { bila alat } \\
\text { dipakai di } \\
\text { pinggang }\end{array}$ \\
\hline
\end{tabular}


Accelerometer memiliki keterbatasan dalam mendeteksi gerakan tubuh bagian atas, kecuali accelerometer ditempatkan pada ekstremitas atas. Accelerometer juga tidak dapat mendeteksi pekerjaan statis dengan akurat. Semua ini berkaitan dengan kenyataan bahwa accelerometer hanyalah alat yang mendeteksi adanya gerakan atau getaran pada bagian tubuh tempat alat tersebut dilekatkan. Akseleromter tidak dapat mengetahui jenis aktivitas yang dilakukan (Schutz et al, 2001).

\section{KESIMPULAN}

Aktvititas fisik merupakan salah satu hal yang sangat penting untuk diperhatikan dalam rangka menciptakan hidup yang sehat. Berbagai peenlitian telah menunjukkan manfaat aktivitas fisik untuk mencegah maupun mengatasi berbagai penyakit. Namun untuk mendapatkan manfaat tersebut dibutuhkan aktivitas fisik yang tepat, tepat dalam hal durasi, frekuensi, intensitas, serta jenisnya. Dalam hal inilah dibutuhkan sarana penilaian aktivitas fisik.

Selama ini telah dikenal berbagai metode penilaian aktivitas fisik, baik secara obyektif maupun subyektif. Salah satu metode penilaian aktivitas fisik secara obyektif yang banyak digunakan saat ini adalah penilaian aktivitas fisik menggunakan accelerometer. Pada dasarnya terdapat tiga jenis accelerometer yang dapat dipilih yaitu accelerometer uniaksial, omnidireksional, dan triaksial.

Dibandingkan dengan metode penilaian aktivitas fisik lainnya accelerometer memiliki beberapa keunggulan, yaitu memiliki ukuran yang kecil, dapat menilai intensitas, durasi dan frekuensi aktivitas fisik karena dilengkapi dengan jam internal dan kemampuan menyimpan data. Penelitian juga telah memungkinkan penghitungan pengeluaran energi berdasarkan hasil pengukuran accelerometer. Begitu banyak rumus yang tersedia memang menimbulkan pertanyaan selanjutnya, bagaimana memilih rumus mana yang hendak digunakan. Perlu diingat bahwa setiap jenis accelerometer dan rumus memiliki kekuatan dan kelemahannya masing-masing. Oleh karena itu tidak ada alat maupun rumus yang dapat dikatakan sebagai yang paling baik dibandingkan yang lainnya. Pemilihan jenis maupun rumus accelerometer yang hendak dipaki harus didasarkan pada tujuan penilaian yang hendak dicapai. Tetapi selain berbagai keunggulan tersebut, accelerometer memiliki kelemahan yaitu harga yang relatif mahal. Hal ini membatasi penggunaannya untuk penelitian berskala luas.

Pada akhirnyaaccelerometer adalah alat yang sangat bermanfaat untuk menilai aktivitas fisik pada individu. 


\section{SARAN}

Melihat pentingnya aktivitas fisik bagi kesehatan, maka disarankan agar dilakukan penelitian mengenai aktivitas fisik di Indonesia dengan menggunakan accelerometer. Penelitian yang disarankan ini dimulai dengan menilai tingkat aktivitas fisik masyarakat Indonesia secara umum maupun di setiap golongan usia atau kelompok populasi khusus (misalnya kelompok individu dengan obesitas, hipertensi, dan lain-lain). Walaupun accelerometer diketahui memiliki harga yang relatif mahal, namun lebih dapat memberikan banyak detail mengenai aktivitas fisik yang dilakukan. Oleh karena itu meski penelitian yang disarankan ini merupakan penelitian yang berskala luas, namun aksmelerometer merupakan sarana penilaian yang dibutuhkan untuk memperoleh informasi yang mendetail.

Hasil dari penelitian ini selanjutnya akan sangat bermanfaat untuk menetapkan kebijaksanaan mengenai hal-hal yang dapat dilakukan untuk meningkatkan taraf kesehatan masyarakat melalui peningkatan aktivitas fisik.

\section{DAFTAR PUSTAKA}

CB Corbin, RP Pangrazi\&BD Franks (2000). Definitions: Health, fitness and physical activity. President's Council on Physical Fitness and Sports Research Digest 3(9):1-8.
Sharratt MT, Hearst WE. (2007). Canada's physical activity guides: Backgrounds, process, and development. Appl. Physiol. Nutr. Metab.;32:S9-S15.

Paterson DH, Jones GR, Rice CL. (2007). Ageing and physical activity: evidence to develop exercise recommendations for older adults. Appl. Physiol. Nutr. Metab. 32:S69108.

Warburton DER, Katzmarzyk PT, Rhodes RE, Shephard RJ. (2007). Evidence-informed physical activity guidelines for Canadian adults. Appl. Physiol. Nutr. Metab.;32:S16-68.

Trost SG. (2007). Measurement of physical activity in children and adolescents. American Journal of Lifestyle Medicine;1:299-314.

Caspersen CJ, Powell KE, Christenson GM. (1985). Physical activity, exercise, and physical fitness: Definitions and distinctions for health-related research. Public Health Reports;100(2):126-31.

Pro-Active Central London. Physical Activity - definitions, recommendations and measurement. Diunduh dari http://www.proactivecentrallondon.org/page.asp?s ection $=00010001000600220001 \&$ s ectionTitle=Physical+Activity++ definitions $\% 2 \mathrm{C}+$ recommendation s+and+measurement pada tanggal 28 Maret 2010.

Haskell WL, Kiernan M. (2000). Methodologic issues in measuring physical activity and physical fitness when evaluating the role of dietary supplements for physically active people. Am J Clin Nutr;72(suppl): 514S-50S. 
U.S. Department of Health and Human Services. 2008. Physical activity guidelines for Americans. Diunduh dari www.health.gov/paguidelines pada tanggal 10 April 2010.

Maddison R, Mhurchu CN. (2009). Global positioning system: A new opportunity in physical activity measurement. International Journal of Behavioral Nutrition and Physical Activity;6:73-80.

Macfarlane DJ, Lee CCY, Ho EYK, Chan KL, Chan D. (2006). Convergent validity of six methods to assess physical activity in daily life. J Appl Physiol;101:1328-34.

Yin B, Goris AHC. 2008. Continuous recognition of daily physical activities using a single triaxial accelerometer. Dalam Bussmann JBJ, Horemans HLD, Hurkmans HLP (editor). International on Ambulatory Monitoring of Physical Activity and Movement Conference Book. Rotterdam.

Corder K, Ekelund U, Steele RM, Wareham NJ, Brage S. 2008. Assessment of physical activity in youth. J Appl Physiol;105:977-87.

Westerterp KR. (2009). Assessment of physical activity: a critical appraisal. Eur J Appl Physiol;105:823-8.

Washburn RA, McAuley E, Katul J, Mihalko SL, Boileau RA. (1999). The Physical Activity Scale for the Elderly (PASE) Evidence for Validity. Journal of Clinical Epidemiology;52(7):643-51.

Badland HM. (2003).Physical activity in a sample of New Zealand professional employees. Sebagai tesis dalam mengambil gelar Master of Health Science di the Auckland University of Technology.

Anderson T. (2005). Time efficiency in computer assissted direct observation of physical activity using SOFIT. Sebagai Tesis pada Department of Exercise Science, Bringham Young University.

Schutz Y, Weinsier RL, Hunter GR. (2001). Assessment of free-living physical activity in humans: An overview of currently available and proposed new measures. Obes Res.;9:368-79.

Plasqui G, Joosen AMCP, Kester AD, Goris AHC, Westerterp KR. (2005). Measuring free-living energy expenditure and physical activity with triaxial accelerometry. Obes Res.;13:1363-9.

Anonim. BioTrainer ${ }^{\mathrm{TM}}$ Clinical Studies. (2010). Diunduh dari http://www.biotrainerusa.com/clini cal.asp pada tanggal 11 April 2010.

Rowlands AV, Eston RG. (2007). The measurement and interpretation of children's physical activity. Journal of Sports Science and Medicine; 6 : 0-6.

Berlin JE, Storti KL, Brach JS. (2006). Using activity monitors to measure physical activity in free-living conditions. Phys Ther. ;86:1137-45.

Tudor-LockeCE, Myers AM. (2001). Methodological considerations for researchers and practitioners using pedometers to measure physical (ambulatory) activity. Research Quarterly or Exercise and Sport.;72 (1):1-12.

Le Masurier GC, Tudor-Locke C. (2003). Comparison of Pedometer and Accelerometer Accuracy under 
Controlled Conditions. Med Sci Sports Exerc.;35(5):867-71.

Tudor-Locke C, Basset DR Jr. How many steps/day are enough? Sports Med. (2004) ;34:1-8.

Dimension Engineering LLC. A beginner's guide to accelerometers. Diunduh dari

http://www.dimensionengineering. com/accelerometers.htm pada 4 Maret 2010.

Texas Instruments. Accelerometer guide. Diunduh dari www2.usfirst.org/2005comp/Manu als/Acceler1.pdf pada tanggal 12 April 2010.

G, Westerterp KR. (2007). Physical activity assessment with accelerometers: An evaluation against doubly labeled water. Obesity;15: 31-9.

Anonim. GT1M Specifications. 2008. Diunduh dari http://www.theactigraph.com/index .php?option $=$ com_docman\&task $=\mathrm{c}$ at_view $\&$ gid $=71 \&$ Itemid $=86$ pada tanggal 2 Mei 2010.

Westerterp KR. (1999). Physical activity assessment with accelerometers.Int J Obes Relat Metab Disord.;23 Suppl 3:S45-9.

Puyau MR, Adolph AL, Vohra FA, Butte NF. (2002). Validation and calibration of phytsical activity monitors in children. Obes Res;10:150-7.

Crouter S, Kerr J. An Introduction to accelerometer data rduction and processing. Diunduh dari www.activelivingresearch.org pada tanggal 24 April 2010.

Trost SG, McIver KL, Pate RR. (2005). Conducting Accelerometer-Based
Activity Assessments in FieldBased Research. Med Sci Sports Exerc.;37(11):S531-43.

Rand D, Eng JJ, Tang PF, Jeng JS, Hung C. (2009). How active are people with stroke?: Use of accelerometers to assess physical activity. Stroke;40:163-8.

Nichols J, Morgan CG, Sarkin JA, Sallis JF, Calfas KJ. (1999). Validity, reliability and calibration of the Tritrac accelerometer as a measure of physical activity. Med Sci Sports Exerc. 31:908-12.

Le Masurier GC. Using Accelerometers to Measure Physical Activity in Physical Education. Dalam The Preliminary Program, (2006) AAHPERD National Convention and Exposition, Salt Lake City. Diunduh dari http://aahperd.confex.com/aahperd/ 2006/preliminaryprogram/abstract_ 8570.htm pada tanggal 4 Maret 2010.

Crouter SE. Clowers KG. Basset, Jr. DR. (2006). A novel method for using accelerometer data to poredict energy expenditure. J Appl Physiol;100:1324-31. 